\title{
Construct Validity of Korean Leisure Sports Instructor Job Crafting Questionnaire Scale (KSIJCQ: Korean Sports Instructor JCQ)
}

\author{
Woo Kyung Kim(Anyang University)， Won Chung Chung (Korea National Sport University) *, \\ Hyu Kyoung Park(Yonsei University)
}

Kim : Sandukro 37Bungil 22 Anyang kyungkido South Korea, Chung : Sangjidaegil 83 Wonju Kangwondo, South Korea, Park : 50 ,Yonseiro Seodaemungu Seoul South Korea

\begin{abstract}
In previous researches, Job Crafting questionnaire to develop is consists of 3 factors which are Task Crafting, Cognitive Crafting, and Relationship Crafting with 12 to 17 items. The purpose of study is to develop JCQ for leisure sports instructor of Korean. 274 valid samples are used for analysis. Data collecting is purposeful sampling. At result, for Korean Sports Instructor Job Crafting Scale is constructed 3 factors with 12 items is constructed by 3 step procedure. KSIJCQ is confirmed on convergent discriminant validity evidence. In conclusion, KSIJCQ is a valid scale of the measuring and distributes Job Crafting of generalization in sports.
\end{abstract}

Key words : JCQ, Job Crafting, construct validity, leisure sports instructor, valid scale

\section{Introduction}

The importance of the employees' satisfaction and happiness turns their work into a meaningful activity (Rezesniewski \& Dutton, 2001) for a job efficient. This means to comprise changing and leading their work tasking(Grant \& Ashford, 2008; Griffin et al, 2007) by themselves. Work tasking with high performance efficient can be defined Job Crafting. In Korea, it was defined 'creating a job'(Kang Hye Won, 2010), 'processing a job' (Kim Sung Kook, \& Hong Ji Sook, 2002), 'performing a professional work'(Kim Chang Ho, 2012), and 're-adjusting an autonomous job'(Kim Geu Ne, 2012). At past, task design was applied in the topdown tasking way design is being interested in growing in the form of a Bottom-up tasking way design, which are more proactive changing their tasks at present. That is the Job Crafting (Kim Woo Kyung, 2017) to apply these task methods(Yim Myung Ki et al., 2014).

Annual salary open data with a website Pay Open and Korea Research(2012) surveyed with 500 employees between 29 and 35 ages for 'the meaning of the day'. They mainly answered the highest response ratio 'to get paid 'by $73.8 \%$ and $17.8 \%$ said 'they prefer to work'. These results showed that most of Korean employees perceived their job just as a way of income. In other words, it showed that money is more important to compensate externally than to make 'rewarding for the job' or 'realizing oneself'. In this circumstance, it is difficult for an organization's members to satisfy their duties indeed. Job Crafting, designed primely to solve these problems, it means that the employees actively to transform the job task that perform to enhance the 
inherent reward(Slemp \& Vella-Brodrick, 2013). Increasing the internal compensation(Yim Bun Jang, 1993) leading external rewards indicates increased job satisfaction or motivation(Wrzesniewski et al., 2010) their actual ethic of work and achievement(Brief, 1998). Therefore, Job Crafting can be constructed to be significant (Gavin, 2014) of an important factor involved in the happy life of employees.

In the study, Job Crafting developed by Wrzesniewski \& Dutton(2001) is consisted in three factors. The first factor is Task Crafting, which changes the physical sorts of the work, the scope, and the way it works. The second task factor is defined the Cognitive Crafting, which changes the sorts of self-perception in the purpose and meaning of one's work. The third task factor is the Relative Crafting(2013), with which intimate is associated(Slemp \& Vella-Brodrick, 2013) peers of similar to interest and skills. In previous studies, Job Crafting was written a positive influence on reducing absenteeism(Ghitulescu, 2006) raised up satisfied with the job task, flow tasks, and individuals performance task. It was the high self-activated sense changing and moderation on confidence action by intervention of task passion(Ghitulescu, 2006) and career enthusiasm as well. In addition, $\operatorname{Ko}(2011)$ explained that employees experienced flow during Job Crafting, and it brings healthy psychologically they will be earned with high level of task impact(Bond, et al. 2008). Also it promoted on the organization's performance impact(Bond et al. 2008). Research by Berg et al.(2010) has shown that Job Crafting is not only cognitive change but also physical change it has resulted in changes in the social, business structure, and challenging resources available.

However, other studies described Job Crafting is too severe to apply to members of different fields of active task engagement by management members or production sector maximizes the organizations' tasks. Moreover, A study by Arnold B Bakker et al.(2012) discussed implications for generalization of results from studies of subjects as employees with higher education.

This study conducted to verify the positive effects of Job Crafting were appropriate for the organization of the leisure sports instructor. In Korea, physical exercise is defined as voluntary and ordinary exercise to promote health and fitness by National Sports Promotion Act in-law(Kim Young Jin, 2016). The leisure sports instructor is defined who directs ordinary physical activities and recreation(Yim Bun Jang, 1993) and has the professional job position of conveying public physical education as well. He guides leisure related health and fitness(Wi Sung Sik, 1993).

According to the Korea National Health Insurance Service(2015) reported leisure sports participants consumed the average annual medical expense for is 267,800 won besides others nonparticipants consumed 556,000 won, which is about twice as high as social budgets (Kim Young Jin, 2016). This result, we can be interpreted as an important way to decrease rising national health care cost. Leisure sports instructor's has to lead a major role of well-being for physical education leader. The role of leisure sports instructor is to increase individual desires and interests of participants carries out(Kraus, 1977) to achieve their goals. Leisure sports 
instructor(Woo Jae Chung, 1987) who recognizes themselves an important leader of sports knowledge.

Therefore the leisure sports instructor's tasks are physical activity coaching and concern with plan management and organizing. Precisely, his roll is guidance for the sports participants in the physical activity (Cho Young Kyu, 2008). In Korea sports researches were noted that the active efforts of the members of the organization in sports(Sports Development Institute 2016; Kim Young Jin, 2016) as a significant role in the task design(Black \& Ashford, 1995; Grant \& Ashford, 2008).

However, previous study the reliability and validity of related the Job Crafting Scale is developed with a measurement tool for task efficiency and euphoria. Through the translating barrier, some bias of Job Crafting Scale could be appeared. Questions have to be controlled to set validity of the evidence against the measure. Furthermore, it has to be developed with the internal validity evidence(Keun So Wu \& Kwum In Su, 2017). In this study, JCQ developed by Slemp \& Valla-Brodrick (2013) was translated into Korean language which is possible to apply and confirm construct validity evidence by Structure Equation Model.

Hence, the purpose of this study is to measure efficiency for the Korean leisure sports instructors' psychological healthy. Fundamentally it would improve their euphoria appropriating the healthy life with Job Crafting, and leads to improve sports participants to guide successfully through.

\section{Method}

\subsection{Subjects}

In this study, data sample was selected to include the leisure sports instructor who recruited participating sport coaching and training as a population. Systematic stratified cluster random sampling method was applied for analyze. The questionnaires were distributed only the participants who sign with agreements. All responses of the questionnaires were reported a self-administration method. 274 data were analyzed, excluding 26 questionnaires that did not respond falsely and invalid. Subject general character is $<$ table $5>$. Subject population consists of $n=274$, gender(male $=178,65 \%$, female $=96,35 \%)$, age range $(20 \leqq 29=191,69.7 \%, 30$ $\leqq 39=55,20.1 \%, 40$ above $=28,10.2 \%$ ), leisure sports instructor experience $(1 \leqq 3 \mathrm{yr}=85,31 \%, 3<\mathrm{yr}=128,46.7 \%$, $5<\mathrm{yr}=61.22 .3 \%)$.

\section{2. measurement}

The JCQ measurement tool applied for this study can be to measure for workers in business(Slemp \& VellaBrodrick, 2013). JCQ factors consist of Tasking Crafting, Cognitive Crafting, and Relationship Crafting they were developed with total of 15 items. Most of measurement scales of JCQ were developed and composed by English, so it is necessary to be translated into Korean literature this study. Before applying for the research, more evidence of validity has to be verified by reverse translation review clearly control of verbal bias. To complete of the process of translation and review, we reviewed and utilized conducting prior study. Content 
validity carries out for the adequacy search of the questions is very important to using scale. A group of professional experts in sports field participates to review content validity screening before applying for the leisure sports instructor. This study were corrected their appropriateness and understanding JCQ that was configured to set for the leisure sports instructor's opinion to screen by 10 different sports experts. Total 3 factors are selected an evidence based on the content of examination with 15 items. All questionnaires were rated at 6 likert scale. Table 1 showed questionnaires are written by English and to translate Korean language.

table 1

JCQ questionnaires in English

\begin{tabular}{|c|c|c|}
\hline & item & contents \\
\hline \multirow[t]{9}{*}{ Task Crafting } & 1 & Introduce new approaches to improve your work. \\
\hline & & 업무능력을 향상시키기 위해 새로운 접근 방식을 도입한다 \\
\hline & 2 & Change the scope or types of tasks that you complete at work. \\
\hline & & 일을 완벽하게 하기 위하여 일의 범위나 유형을 변화시킨다. \\
\hline & 3 & Introduce new work tasks that better suit your skills or interests. \\
\hline & & 능력이나 흥미를 잘 활용 할 수 있는 새로운 일을 시도한다. \\
\hline & 4 & Choose to take on additional tasks at work. \\
\hline & & 추가적인 업무도 수행한다. \\
\hline & 5 & $\begin{array}{l}\text { Give preference to work tasks that suit your skills or interests. } \\
\text { 능력이나 흥미가 잘 반영된 업무를 선호한다. }\end{array}$ \\
\hline \multirow{6}{*}{$\begin{array}{l}\text { Cognitive } \\
\text { Crafting }\end{array}$} & 6 & Think about how your job gives your life purpose. \\
\hline & & 내 일과 삶의 목표가 연결되는가를 생각한다. \\
\hline & 7 & $\begin{array}{l}\text { Remind yourself about the significance your work has for the success of the organization. } \\
\text { 맡은 업무가 조직의 성공을 위해 중요하다는 것을 상기한다. }\end{array}$ \\
\hline & 8 & $\begin{array}{l}\text { Remind yourself of the importance of your work for the broader community. } \\
\text { 일이 우리 사회에 기여하는 바를 생각한다. }\end{array}$ \\
\hline & 9 & $\begin{array}{l}\text { Think about the ways in which your work positively impacts your life. } \\
\text { 내 일이 내 삶에 어떤 긍정적 영향을 미치는지 생각한다. }\end{array}$ \\
\hline & 10 & $\begin{array}{l}\text { Reflect on the role your job has for your overall well-being. } \\
\text { 내 일이 행복하게 살아가는 것에 잘 반영되는지 생각한다. }\end{array}$ \\
\hline \multirow{6}{*}{$\begin{array}{l}\text { Relationship } \\
\text { Crafting }\end{array}$} & 11 & Make an effort to get to know people well at work. \\
\hline & & 직장에서 동료와 잘 지내려고 노력한다. \\
\hline & 12 & $\begin{array}{l}\text { Engage in networking activities to establish more relationships. } \\
\text { 업무와 관련된 친목활동과 모임 등을 주도하고 적극 참석한다. }\end{array}$ \\
\hline & 13 & $\begin{array}{l}\text { Organize special events in the workplace (e.g., celebrating a co-worker's birthday). } \\
\text { 직장에서 특별한 이벤트(예, 동료의 생일 파티)를 주도한다. }\end{array}$ \\
\hline & 14 & $\begin{array}{l}\text { Choose to mentor new employees(officially or unofficially). } \\
\text { 공식적, 비공식적으로 후배나 신입직원의 멘토가 되어준다. }\end{array}$ \\
\hline & 15 & $\begin{array}{l}\text { Make friends with people at work who have similar skills or interests. } \\
\text { 회사에서 나의 업무와 흥미가 비슷한 사람들과 친밀하게 지내려 노력한다. }\end{array}$ \\
\hline
\end{tabular}




\subsection{Data processing}

Data was analyzed by using the statistical program SPSS 23.0 and AMOS 23.0. Analysis of the reliability as internal consistency was confirmed by the internal consistency, with Cronbach's alphas. To verify the discriminant validity and convergent validity evidence, the data was analyzed systematic procedure. The discriminant validity and convergent validity evidence were estimated on Composite Reliability(CR) and Average Variance Extracted(AVE). A concept of the CR is measuring of the internal consistency of the variables it considers reasonably if the value is higher than 0.7(Bae Bung Yeul, 2009; Hair, Anderson, Tatham, \& Black., 1998). The AVE represents the explanatory magnitude the value is greater than 0.5(Kim Gae Soo, 2009; Formall \& Larcker, 1981). Discriminant validity is confirmed on critical value the sum of square value of the correlation coefficient between the two developed variables. It can be acceptable if critical value of AVE of both variables is less than the value of AVE estimated valid(Kim Gae Soo, 2009; Formall \& Larcker, 1981). Cronbach's alpha was estimated at .05 by critical value.

\section{Results}

In this study, we analyzed to confirm evidence of the validity, or the developed measurement scale of the KSIJCQ were a valid measure for the leisure sports instructors. Based on the reviewed previous studies measurement variables, configure the relevant factors and items were confirmed the test results which were analyzed with the Structure Equation Model to Confirmatory Factor Analysis(CFA). First analysis of reliability appeared Cronbach's $\alpha=.902$. Practically the model sample size(Chung won Chung, 2016 ; Hong Sae Hee, 2000) has to be applied by validating research methods. The critical value of the model was set CFI and TLI $>.90$, RMSEA $<.08$ (Kim Gae Soo, 2009). The result of analysis appeared that $\mathrm{CFI}=.871, \mathrm{TLI}=.844$, and RMSEA appeared as .098 unacceptable value. Model fit effect size indicates each factor to present by standardization coefficient as $R^{2}$ and Squared Multiple Correlation(SMC). Since convergent validity evidence of latent variable of Relationship Crafting appeared $\mathrm{CR}=.877, \mathrm{AVE}=.588$. Thus hypothesis was confirmed acceptable like critical value of statistical significance $(\mathrm{CR} \geq .70, \mathrm{AVE} \geq .50)$. Task Crafting $\mathrm{CR}=.785$, $\mathrm{AVE}=.431$. Cognitive Crafting $\mathrm{CR}=.804, \mathrm{AVE}=.454$ appeared as the critical value of $\mathrm{CR}$ statistical significance level acceptable( $(\mathrm{R} \geq .70, \mathrm{AVE} \geq .50)$, while $\mathrm{AVE} \geq .50$ was not acceptable. Item $\mathrm{Q} 4, \mathrm{Q} 8$ were also not acceptable of convergent validity be unsatisfactorily because of SMC Comparatively few poor (Hair et al., 1998).

table 3

3 trial model fit

\begin{tabular}{cccccccc}
\hline trial & $\chi^{2}$ & $d f$ & $Q$ & CFI & TFI & RMSEA & $p$ \\
\hline 1 & 429.807 & 86 & 4.998 & .871 & .844 & .098 & .001
\end{tabular}




\begin{tabular}{lllllllll}
2 & 238.024 & 61 & 3.902 & .932 & .914 & .085 & .001 \\
3 & 131.906 & 48 & 2.748 & .964 & .951 & .068 & .001 \\
\hline
\end{tabular}

table 4

\begin{tabular}{|c|c|c|c|c|c|c|c|}
\hline trial & latent variable & item & $\beta$ & $\mathrm{SE}$ & $\mathrm{SMC}$ & $\mathrm{CR}$ & AVE \\
\hline \multirow{13}{*}{1} & Task Crafting & $\mathrm{t} 1$ & .708 & .356 & .501 & \multirow{4}{*}{.787} & \multirow{4}{*}{.483} \\
\hline & \multirow{7}{*}{ Cognitive Crafting } & $\mathrm{t} 2$ & .546 & .725 & .298 & & \\
\hline & & $\mathrm{t} 3$ & .739 & .373 & .546 & & \\
\hline & & t5 & .653 & .440 & .426 & & \\
\hline & & c6 & .663 & .436 & .440 & \multirow{4}{*}{.827} & \\
\hline & & c7 & .710 & .346 & .504 & & \multirow{3}{*}{.545} \\
\hline & & c9 & .711 & .340 & .506 & & \\
\hline & & c10 & .651 & .441 & .424 & & \\
\hline & \multirow[t]{5}{*}{ Relationship Crafting } & r11 & .662 & .305 & .438 & \multirow{5}{*}{.877} & \multirow{5}{*}{.588} \\
\hline & & r12 & .752 & .370 & .566 & & \\
\hline & & r13 & .719 & .387 & .517 & & \\
\hline & & r14 & .740 & .385 & .548 & & \\
\hline & & $\mathrm{r} 15$ & .731 & .379 & .534 & & \\
\hline \multirow{13}{*}{2} & \multirow[t]{4}{*}{ Task Crafting } & t1 & .708 & .356 & .501 & \multirow{4}{*}{.787} & \multirow{4}{*}{.483} \\
\hline & & $\mathrm{t} 2$ & .546 & .725 & .298 & & \\
\hline & & $\mathrm{t} 3$ & .739 & .373 & .546 & & \\
\hline & & t5 & .653 & .440 & .426 & & \\
\hline & \multirow[t]{4}{*}{ Cognitive Crafting } & c6 & .663 & .436 & .440 & & \\
\hline & & c7 & .710 & .346 & .504 & \multirow{3}{*}{.827} & \multirow{3}{*}{.545} \\
\hline & & c9 & .711 & .340 & .506 & & \\
\hline & & $\mathrm{c} 10$ & .651 & .441 & .424 & & \\
\hline & \multirow[t]{5}{*}{ Relationship Crafting } & r11 & .662 & .305 & .438 & \multirow{5}{*}{.877} & \multirow{5}{*}{.588} \\
\hline & & r12 & .752 & .370 & .566 & & \\
\hline & & r13 & .719 & .387 & .517 & & \\
\hline & & r14 & .740 & .385 & .548 & & \\
\hline & & $\mathrm{r} 15$ & .731 & .379 & .534 & & \\
\hline \multirow{13}{*}{3} & Task Crafting & $\mathrm{t} 1$ & .708 & .356 & .501 & \multirow{4}{*}{.787} & \multirow{4}{*}{.483} \\
\hline & \multirow{7}{*}{ Cognitive Crafting } & $\mathrm{t} 2$ & .546 & .725 & .298 & & \\
\hline & & $\mathrm{t} 3$ & .739 & .373 & .546 & & \\
\hline & & t5 & .653 & .440 & .426 & & \\
\hline & & c6 & .663 & .436 & .440 & \multirow{4}{*}{.827} & \\
\hline & & c7 & .710 & .346 & .504 & & \multirow{3}{*}{.545} \\
\hline & & c9 & .711 & .340 & .506 & & \\
\hline & & $\mathrm{c} 10$ & .651 & .441 & .424 & & \\
\hline & Relationship Crafting & r11 & .662 & .305 & .438 & & \\
\hline & & $\mathrm{r} 12$ & .752 & .370 & .566 & & \\
\hline & & r13 & .719 & .387 & .517 & .877 & .588 \\
\hline & & r14 & .740 & .385 & .548 & & \\
\hline & & $\mathrm{r} 15$ & .731 & .379 & .534 & & \\
\hline
\end{tabular}

After analyzed first result, we deleted item 4 and 8, then process of next step of CFA was conducted. Model fit 
of $\mathrm{CFI}=.932, \mathrm{TLI}=.914$ appeared significantly acceptable, while $\mathrm{RMSEA}=.085$ was unsatisfied.

Second step of the analysis result appeared that convergent validity evidence in latent variable of Cognitive Crafting was $\mathrm{CR}=.827, \mathrm{AVE}=.545$, Relationship Crafting was $\mathrm{CR}=.877, \mathrm{AVE}=.588$ was acceptable. If hypothesis was accepted significantly by critical $(\mathrm{CR} \geq .70, \mathrm{AVE} \geq .50)$, Task Crafting appeared $\mathrm{CR}=.787$, $\mathrm{AVE}=.483$. However, Task Crafting AVE was unacceptable by critical value(AVE $\geq .50)$. In second analysis step, we decided to delete item 4 and 8 . Model fit as CFI=., TLI appeared significantly acceptable while RMSEA $=.085$ was unsatisfied.

Therefore, there was item 2 in Task Crafting was deleted by SMC (Hair et al., 1998), then it analyzed by CFA. CFA result showed $\mathrm{CFI}=.964, \mathrm{TLI}=.951$, RMSEA were satisfied acceptable. In the table 4, revised items' convergent validity appeared Task Crafting $\mathrm{CR}=.776, \mathrm{AVE}=.538$, Cognitive Crafting $\mathrm{CR}=.827, \mathrm{AVE}=.545$, and Relationship Crafting $\mathrm{CR}=.877$, $\mathrm{AVE}=.588$, consequently 3 factors were satisfied critical value significantly $(\mathrm{CR} \geq .70, \mathrm{AVE} \geq .50)$.

table 5

between factors discriminant validity

\begin{tabular}{ccc}
\hline latent factor & $R^{2}$ & latent variable \\
\hline TaskCrafting $\leftrightarrow$ Cognitivecrafting & $.725(526)$ & $538 \leftrightarrow .545$ \\
TaskCrafting $\leftrightarrow$ RelationshipCrafting & $.611(373)$ & $538 \leftrightarrow .588$ \\
Cognitivecrafting $\leftrightarrow$ RelationshipCrafting & $587(345)$ & $545 \leftrightarrow .588$ \\
\hline
\end{tabular}

Finally, to confirm the discriminant validity evidence identification of model, Figure 3, that correlation coefficient(R2) and mean variance extraction(AVE) of determination between latent variables were compared(AVE). If the correlation coefficient(R2) indicates smaller than the AVE between latent variables, it is decide to accept discriminant validity based on statistical significance.

As a result, finally discriminant validity evidence was verified with factors as latent variable Task Crafting, Cognitive Crafting, and Relationship Crafting. Therefore, model was designed to measure the KSIJCQ of leisure sports instructor consists of 3 factors with 12 items that could be identified as a valid measurement tool and scale in Korea. 


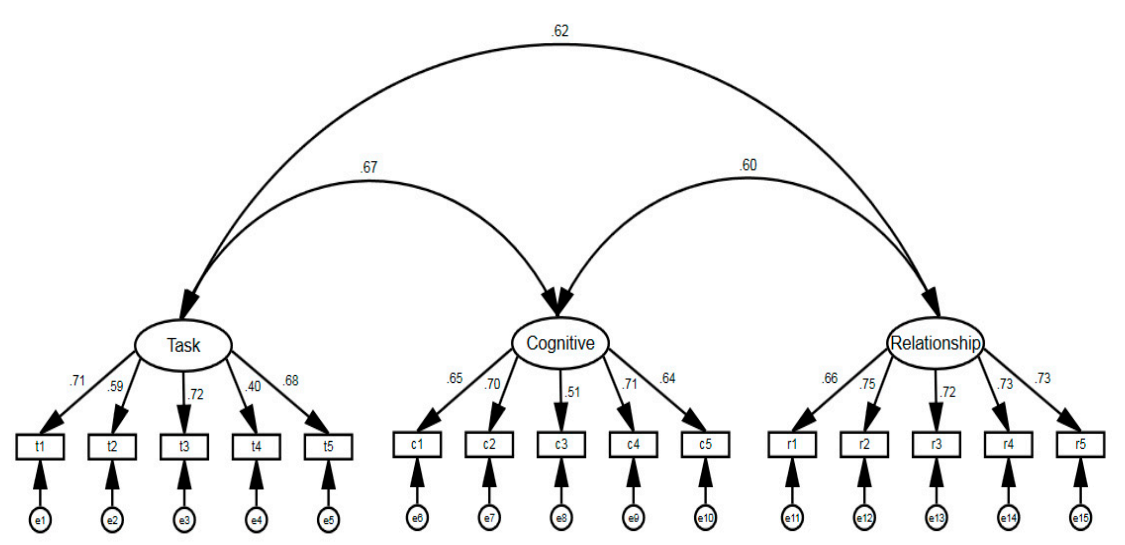

Fig 1. Job Crafting Scale 15 items

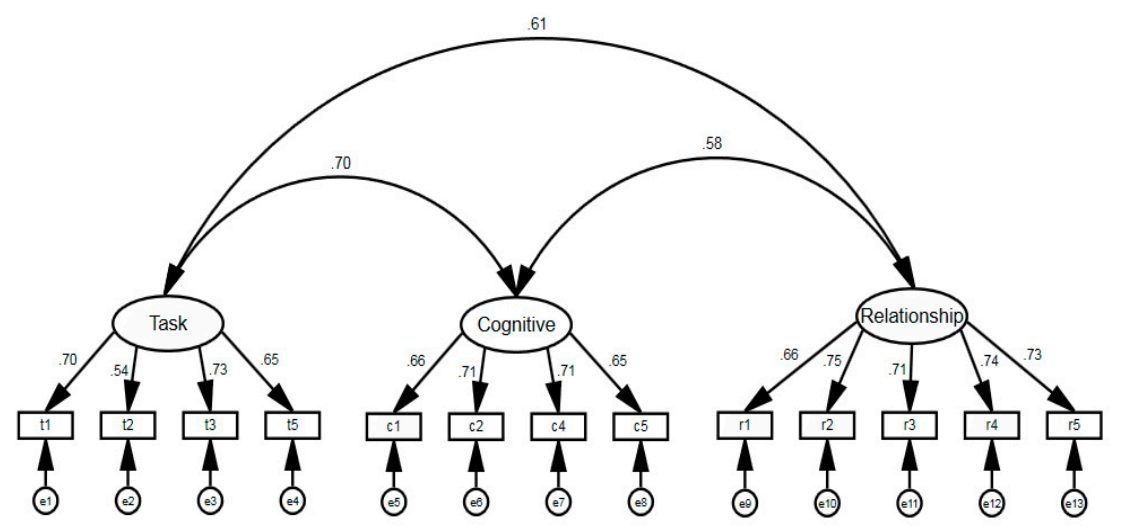

Fig 2. Job Crafting Scale 13 items

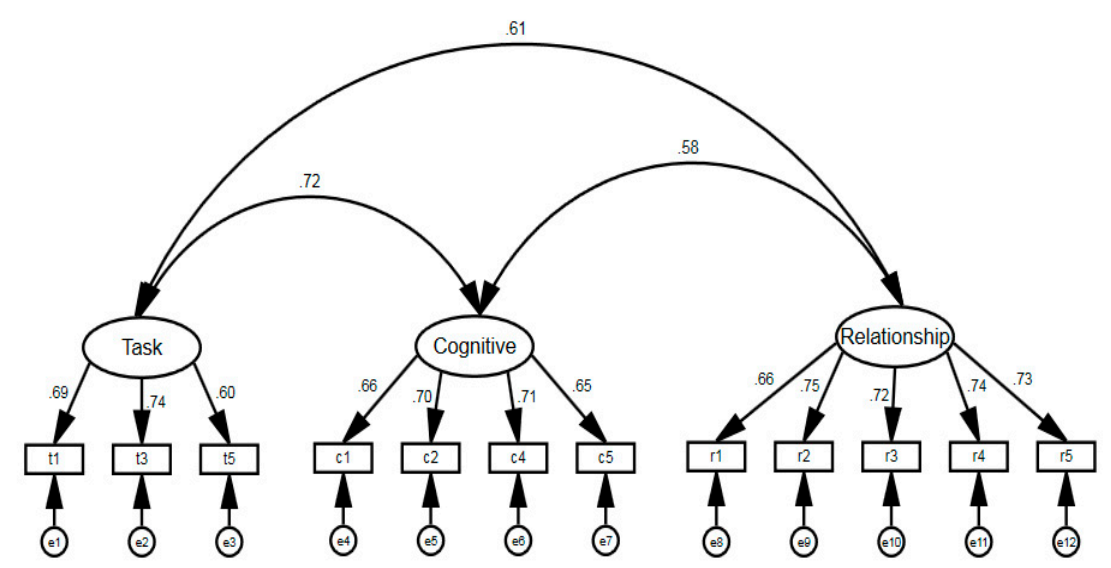

Fig 3. Job Crafting Scale 12 items 


\section{Discussion.}

In general, most of company organizations want their employees to be able to recognize and effectively do their jobs(Yim Myung Ki et al., 2014). However, they must understand the value of their job tasking in order to achieve the goal(Brown, 2002). It is difficult to look over employees' creative modifications and changes to lead the task on their own. Their purpose and implication should be involved to Job Crafting, which gives meaning of a task to alter or adjust job tasking situation in many ways that enables ones to feel the sense of well-being immersing in work.

A research has shown that job role and job autonomy of difference could overcome which company organization has been shown in common. There was some effects(Berg et al., 2010) that employees can transform their perspectives and perception of their work positively. For the employee of the organization could be attempted Job Crafting actively. Moreover, attempting Job Crafting, companies can be able to have some positive effects on both individual employee and organization if they allow and encourage. Among the scales to measure Job Crafting(Wrzesniewski \& Dutton, 2001), developed by Slemp \& Valla-Brodrick (2013) scales were generally being analyzed for appropriate. Usual process for verifying discriminant and convergent validity is conducted through the verifications. As a result, final JCQ scale for leisure sports instructor was confirmed on optimal measurement tool that was classified into categorization. If Interpreting this results, JCQ(Slemp \& Valla-Brodrick, 2013) support the fact that they punctuate discriminatively in response.

From the analysis, SMC, item 4, 8, and 13 showed lower effect which have to be deleted. The minimum number of factors that make up the scale is based on criteria that meet the results of the prior study reported as relevant (Bollen, 1989) to support hypothesis. Previous research, JCQ has developed by Slemp \& Valla-Brodrick(2013) to construct 3 factors 12 items from 334 professional workers. Back Su Jin(2016) developed JCQ scale grounded Tims, et al.(2012) JCQ, modified by Petrou et al.(2012), as a valid measurement. In Back Su Jin's(2016) research. 13 items test score increased, and the organization task efficiency was improved to report representing improvement(Searle \& Lee, 2015). This result supports that JCQ effects on workers performance to be similar purpose to this study is a very important suggestion of further studies. Korean version JCQ can be also adopted as a feasibility study based on measurement scale attracting from Slemp \& Valla-Brodrick(2013). Therefore, that result supports KSIJCQ is a validated measurement scale since constructed. Consequently, JCQ scale translated to the Korean, has been set to establish, it gives and supports to the fact that the validating results for measuring the Job Crafting evaluation.

The purpose of this study is conducted to confirm the validity of the measurement scale using JCQ scale for the leisure sports instructor. The results of this study followed conclusions. First, if JCQ developed by Slemp \& Vella-Brodrick was applied for Korean leisure sports instructor extracted 3 factors. Second, if JCQ developed by Slemp \& Vella-Brodrick was identified with 12 items applying for Korean leisure sports instructor. Third, if 
convergent and discriminant evidence have been validated for developed by Slemp \& Vella-Brodrick, and it is possible to apply to Korean leisure sports instructor.

Recently several measurement scales of JCQ that are currently used for measuring employees' Job Crafting have been applied with a variety of different metrics. However, there is a limitation to apply a reasonable measurement of employee's attributes the developed scale a particular job tasking.

Through this research process, I suggest that JCQ has applied proven measurement to various subjects are conducted later, and the satisfaction of the leisure sports instructor satisfaction of the related field in their task. For further research, Job Crafting not only cognitive changing but also physical health changing as social, task structure, and challenging desire(Berg et al., 2010). This study is intended to examine the validity of this research using the statistical techniques of Job Crafting Scale(JCQ) developed who works in sport related field and physical education.

In the future, we expected to contribute to more relevant study to follow-up researchers using Job Crafting Scale. Through the redetecting and constructing process, to ensure a leisure sports instructor can be able to enhance his and her job tasking satisfaction and happiness to concern.

\section{Conclusion}

The purpose of this study is conducted to confirm the validity of the measurement scale using KSIJCQ scale of leisure sports instructor. The results of this study yielded the following conclusions. First, KSIJCQ(Slemp \& Vella-Brodrick, 2013)was applied for Korean leisure sports instructor extracted 3 factors. Second, KDIJCQ was identified with 12 items for applying Korean leisure sports instructor. Third, convergent and discriminant evidence have also been validated KSIJCQ is possible to apply to Korean leisure sports instructor in Korea.

Recently several JCQ scales are currently used measuring employees' Job Crafting has been applied with a variety of different metrics. However, there is some limitation to apply a reasonable measurement of employee's attributes the developed scale to a particular job tasking.

In conclusion, redetecting and constructing process, to ensure measurement scales enhance task performance and employees' happiness, concerning with Job Crafting carries out to make sense as a reasonable measurement method.

\section{Reference}

$\operatorname{ACSM}(1990)$. The recommended quantity and quality of exercise for developing and maintaining cardiorespiratory 
and muscular fitness in healthy adults. Medicine and Science \& Sports Exercise, 22(2), 265-274.

Adam, M. G., \& Susan, J. A. (2008). The dynamics of proactivity at work. Research in organizational behavior, 28, 3-34.

Anne, T. B., Samuel, F. B., Martin, J. B., Jeffrey, B., Cross, J. H., Walter, V. E. B., Jerome, E., Jacqueline, F., Tracy, A. G., Gary W. M., Solomon L. M., Douglas N., Perrine, P., \& Ingrid E. S.(2005-2009). Revised terminology and concepts for organization of seizures and epilepsies: Report of the ILAE Commission on Classification and Terminology. epilepsia, 51(4), 676-685.

Arnold, B. B., Maria, T., \& Daantje, D. (2012). Proactive personality and job performance: The role of job crafting and work engagement. Human Relations, 65(10), 1359-1378.

Bae, B. Y.(2009). AMOS 17.0 SEM modeling, Seoul: Chungram.

Baek, S. J.(2016). The structural relationship among job crafting, work engagement and change-oriented behavior.

Ph. D. Dissertation, Chungang University, Seoul.

Bang, E. J., \& Seo, Y. W.(2017). The effect of perceived overqualification on job crafting : Focused on mediation effect of organization based self-esteem. Korean Journal of Psychology, 30(1), 77-100.

crafting at different ranks: When proactivity requires adaptivity. Journal of Organizational Behavior, 31(2-3), 158-186.

Black, J. S. \& Ashford, S. J.(1995). Fitting In or Making Jobs Fit: Factors Affecting Mode of Adjustment for New Hires. Human Relation, 48(4), 421-427.

Bollen, K. A. (1989). New Incremental Fit Index for General Structural Equation Models.

Sociological Methods \& Research, 17(3), 303-316.

Bond, G. R., Drake, R. E., \& Becker, D. R.(2008). An update on randomized controlled trials of evidence-based supported employment. Sychiatric Rehabilitation Journal, 31(4), 280-290.

Brief, A. P.(1998). Attitudes in and around organizations, CA: Sage, Thousand Oaks.

Brown, D.(2002). The role of work and cultural values in occupational choice, satisfaction, and success: a theoretical statement. Journal of Counseling and Development, 80, 48-56.

Choi, O. J.(2014). The Effect of Workers' Job Crafting on Job Attitude. M.A. Dissertation, Korea aerospace University, Kyungkido.

Chung, W, C(2016). Development and Validation of the Assessment Scale for Art Competition. Ph. D. Dissertation, Korea National Sport University, Seoul.

Fornell, C., \& Larcker, D. F.(1981). Evaluating structural equation models with unobservable variables and measurement error. Journal of marketing research, 18, 39-50.

Gary R., Drake, Robert E., Becker, \& Deborah R.(2008). An update on randomized controlled trials of evidencebased supported employment. Psychiatric Rehabilitation Journal, 31(4), 280-290.

Gavin R. S, \& Dianne A. V.(2014). Optimising Employee Mental Health: The Relationship Between Intrinsic Need Satisfaction, Job Crafting, and Employee Well-Being. J Happiness Study, 15, 957-977.

Ghitulescu, B. (2006). Job crafting and social embeddedness at work. Ph.D.dissertation, University of Pittsburgh.

Hair, J. F., Anderson, R., Tatham A., \& Black D.(1998). Multivariate data analysis, 5th ed., Prentice-Hall International.

Hong, S. H.(2000). The Criteria for Selecting Appropriate Fit Indices in Structural Equation Modeling and Their Rationales. Korean psychological association, 19(1). 161-177. 
Io, K.(2011). Crafting a job: Creating optimal experiences at work . Ph. D. Dissertation, Claremont Graduate University, California.

Jo, Y, K.(2008). The influence of job satisfaction of sport for all leaders on turnover. M.A. Dissertation, Soongsil University, Seoul.

Kang, H. W.(2010). The effect of Job Crafting, Role Perception, and Job Characteristics on Job Attitude - Centering at moderator role of demographic variables . Ph. D. Dissertation, Hongik University, Seoul.

Kang, J., B.(2016). The Impact of Job Resources and Psychological Capital on Job Crafting. Department of International Business. Ph. D. Dissertation, Kyung Hee University.

Keun, S. W. \& Kwun, I. S.(2017). On Job Crafting - The Antecedents of Job Crafting and the Mediating Role of Role Breadth Self-Efficacy. Korean Association Of Human Resource Development, 20(1), 95-123.

Kim, C. H.(2012). A study on the impact of authentic leadership on the job crafting of employees and it's process.

Ph. D. Dissertation, Hanyang University, Seoul.

Kim, G. S.(2009). AMOS 18.0 analysis of SEM, Seoul: Hannarae Academy.

Kim G. N.(2012). How job characteristics and job crafting influence organizational achievement. M.A. Dissertation, Sookmyung University, Seoul.

Kim, S. K., \& Hong, J. S.(2002). New Approaches to Job Analysis. Korean corporation management association, 16, 223-244.

Kim, W. K.(2017). A Study on the Development of Expertise the Instructors to Promote Life Sports, The Korea Entertainment Industry Association. 11(6), 153-163.

Kim, Y. J.(2016). Impact of the senior's fitness instructor's job environment on job satisfaction. M.A. Dissertation, Korea National Sport University, Seoul.

Leana, C., Appelbaum, E., \& Shevchuk, I.(2009). Work process and quality of care in early childhood education: The role of job crafting. Academy of Management Journal, 52, 1169-1192.

Lee, S. H., Ko, S. H., \& Mun, H. H.(2016). Relationship between organizational virtue perceived by organizational members and job performance - focusing on the mediating effect of positive psychological capital. Management and information system review, 35(5), 81-108.

Lyons, P. (2008). The crafting of jobs and individual differences. Journal of Business Psychology, 23, 25-36.

Mark A. G., Andrew N., \& Sharon K. P.(2007). A New Model of Work Role Performance: Positive Behavior in Uncertain and Interdependent Contexts. Academy of management journal, 50(2), 327-347.

Mueller, R. O.(1996). Basic principles of structure equation modeling: An introduction to LISREL and EQS, Springer-ver lag.

National Health Insurance Service(2015). http://www.nhis.or.kr

Pay Open and Korea Research (2012). http://www.newswire.co.kr. A Survey on the Recognition of Korean Workers.

Petrou, P., Demerouti, E., Peeters, M. C. W., Schaufeli, W. B., \& Hetland, J.(2012). Crafting a job on a daily basis: Journal of Original Behavior, 33(8), 1120-1141.

Petrou, P., Demerouti, E., Schaufeli, W. B., Wilmar B(2015). Job crafting in changing organizations: Antecedents and implications for exhaustion and performance. Journal of Occupational Health Psychology, 20(4), 470-480. 
Searle, B. J. \& Lee, L. (2015). Proactive coping as a personal resource. International Journal of Stress Management, 22(1), 46-69.

Slemp, G. R., \& Vella-Brodrick, D. A.,(2013). The job crafting questionnaire: A new scale to measure the extent to which employees engage in job crafting. International Journal of Wellbeing, 3(2), 126-146.

Tims, M., \& Bakker, A. B.(2010). Job crafting: Towards a new model of individual job redesign. South African Journal of Industrial Psychology, 36, 1-9.

Tims, M., Bakker, A. B., \& Derks, D.(2012). Development \& validation of the job crafting scale. Journal of Vocational Behavior, 80, 173-186.

Tims, M., Bakker, A. B., \& Derks, D.(2012). Proactive personality and job performance: The role of job crafting and work engagement. Human Relation, 65(10), 1259-1282.

Tom J. B.(2002). The Customer Orientation of Service Workers: Personality Trait Effects on Self- and Supervisor Performance Ratings. Journal of marketing, 39(1), 110-119.

Wi, S. S.(1993). The proper cultivation system for training professional leader. Korean society of sports leisure studies, 1(1) 19-29.

Wrzesniewski, A. \& Dutton, J. E.(2001). Crafting a job: Revisioning employees as active crafters of their work. Academy of Management Review, 26, 179-201.

Wrzesniewski, A., Dutton, J. E., \& Debebe, G.(2003). International sensemaking and the meaning of work. Research in Organizational Behavior, 25, 93-135.

Wrzesniewski, A., Berg, J. M., \& Dutton, J. E.(2010). Managing Yourself, Turn the job you have into the Job you want: Havard Business Review, June.

Yim, B. J.(1993). Korea Sports Promotion Foundation.

Yim, M. K., Ha, Y. J., Oh, D. J., \& Son, Y. W.(2014). Validation of the Korean Version of Job

Crafting Questionnaire (JCQ-K). International Business Journal, 21(4),181-206. 